\title{
Drivers of Integration? EU Agency Board Members on Transboundary Crises
}

\begin{abstract}
The European Union continuously faces transboundary crises (TBCs), such as the 1996 and 2000 outbreaks of 'mad cow disease', or the 2015 refugee crisis. Within this context, European Union agencies (EAs) have emerged as technical repositories that are capable of addressing such crises more efficiently than intergovernmental cooperation. However, their effective implication in transboundary crisis management largely varies, as many different degrees of involvement can be observed. Different angles can be adopted to make sense of variation in the response of agencies to TBCs; hence, this study focuses on the role of EA management boards. These boards epitomize the unique nature of EU institutions, in that they represent the Member States and integrate their network capabilities into a single entity. Our study assesses perceptions of board members concerning three aspects related to the capacity of agencies to respond to TBCs: decisionmaking, coordination and resources, based on a survey distributed among board members and a biographical database.
\end{abstract}




\section{Introduction}

The European Union has faced and still faces continuous transboundary crises (TBCs) on a continental scale whose management and resolution requires institutional responses and the design of specific procedures (Boin et al. 2014). Examples of these are the 1996 and 2000 outbreaks of 'mad cow disease', the 2008 financial crisis, or the 2015 refugee crisis. From a policy perspective, these experiences may help rethink the integration process, identify potential areas for improvement and draw attention to existing coordination problems among different actors in Europe.

European Union agencies (EAs) have provided new capabilities for EU-wide policies in different domains (e.g. the economy, public health, or security). Consequently, they have become technical repositories that cope with crises once they have been officially recognized. Actually, some EAs emerged in response to earlier crises (e.g. the European Food Safety Authority - EFSA, the European Centre for Disease Prevention and Control - ECDC, or the European Banking Authority - EBA), while others evolved from existing networks of specialized institutions at the Member-State level (Blauberger and Rittberger 2015; Coen and Thatcher 2008; Rittberger and Wonka 2013). However, the extent and nature of the roles that EAs play in solving TBCs vary largely (Authors).

Using the analytical framework proposed by Ansell et al. (2010) and Boin et al. (2015), we focus on two crucial aspects concerning the capacity of EAs to develop managerial capabilities that are later used in TBC responses: decision-making and coordination. As a crosscutting element of both aspects, we also examine the availability of resources in crisis responses. To this end, we concentrate on the role of EA management boards, as these bodies epitomize the unique nature of EU institutions. Their members are mainly 
EU officials and some individuals appointed by the Member States to represent them. This circumstance makes management boards critical to link the national and the European levels when it comes to agency decision-making. Although management boards are the most visible decision-making bodies within EAs (e.g. Busuioc 2013; Egeberg and Trondal 2011), their role in TBCs is still underexplored. On the basis of findings extracted from a series of organizational studies (Brewer 2006; Pandey and Rainey 2006; Wright 2004; Rainey and Jung 2015), our study pays attention to perceptions among management board members, as these may reflect the de facto organizational performance of such bodies.

On the one hand, we examine which variables influence the views of board members on the involvement of EAs in TBCs through two theoretical lenses that have been put forward in the literatures on European integration and agencification as regards agency creation. The first perspective is based on a functional logic, which argues that EU agencies can be understood as the outcome of a technical approach to regulatory governance (Thatcher 2011). The second perspective is based on a political-institutional logic, which argues that EAs can be understood as the result of a political consensus among EU and national institutions (Kelemen and Tarrant 2011). Focusing on the functional logic, we examine whether board members from agencies with a clear mandate regarding risk assessment perceive crises differently to those from EAs whose mandate is less clear in this respect. Taking a similar perspective, we compare board members from regulatory and nonregulatory agencies. We expect to find more support for involvement in agencies whose mandates include risk management than in those where such is not the case, and more in regulatory than nonregulatory bodies. As our third variable, but at the individual level, we examine whether the curricular characteristics of 
EA board members lead to different perceptions about crisis management. In particular, we hypothesize that board members with strong scientific backgrounds will be more in favor of EA involvement during crises than board members without scientific backgrounds. Focusing on the political-institutional perspective, we analyze how perceptions among board members regarding the degree of consensus among relevant EU players and Member States on the causes of crises affect board member views on the role of an EA in a TBC. This variable involves political reasoning on the part of the respondent, in that perceptions of consensus on this matter might prompt board members to view a given EA as playing a salient role in a $\mathrm{TBC}$ response.

In addition, our study examines whether board members perceive certain political principals - specifically, the European Commission, national regulatory agencies (NRAs), and national governments - to be more important than others in decisionmaking and coordination processes when EAs confront crises. In this way, we also control for the perception of power in EU institutions. This analysis is relevant as most board members are representatives of Member States. These individuals may generate dynamics that favor the national agencies or ministries of their appointing countries over European bodies. Yet, previous studies have diverged on this point: for example, Egeberg and Trondal (2011) and Thatcher (2011) highlighted the relevance of the Commission in shaping EA decision-making, while other studies (e.g., Busuioc 2012) have emphasized the role of the Member States.

This article aims to contribute to the literature that focuses on the convergence of EUlevel TBC management and the role of EU institutions (Backman and Rhinard 2017; Boin 
et al. 2014; Boin and Rhinard 2008; Moloney 2010; Olsson 2009; van Ondarza and Parkes 2010). More generally, this article aims to contribute to our understanding of EA behavior during crises while examining its potential to play a significant role in the European polity. The two approaches, functional and political, sustaining our explanatory variables have been treated by some authors as rival logics. On the one side, some scholars have suggested that the emergence of agencies is an answer to the coordination dilemma among EU Member States (Majone 1996; Eberlein and Grande 2005; Sabel and Zeitlin 2010; Levi-Faur 2011; Rittberger and Wonka 2013; Heims 2016). In this case, delegation is not a political issue, but a matter of efficiency. On the other side, a political argument regarding the creation of agencies identifies this process 'as a strategic, political compromise between main institutional actors at the EU level' (Busuioc, 2013: 73); according to Kelemen and Tarrant (2011), the degree of distributional conflict in the policy sector in question - along with the degree of influence exercised by supranational actors - may shape the design and strength of these bodies. Our study seeks to contribute to such debate by identifying the rival or complementary nature of both explanatory approaches regarding the involvement of agencies in crisis responses.

The paper is organized as follows. Firstly, we discuss the literature that links the performance of EAs to TBC management. Secondly, we offer an analytical framework, discuss our variables in detail, and formulate the hypotheses that will be empirically tested. Thirdly, we present our empirical findings and examine the results obtained. Finally, a concluding section places our results in the context of the different theoretical perspectives discussed above. 


\section{EU agency management boards in transboundary crisis responses: analyzing perceptions on decision-making, coordination and resources}

A 'crisis' is deemed as a 'serious threat to the basic structures or the fundamental values and norms of a system, which under time pressure and highly uncertain circumstances necessitates making vital decisions' (Rosenthal et al. 1989: 10). When it comes to transboundary crises (TBCs), these reflect the reality that current crises may cross national and administrative boundaries (Ansell et al. 2010). In particular, the challenge of TBCs resides in their complexity due to the number of participants involved, the divergent agendas they pursue, and the obstacles to reaching coherent responses (Ansell et al. 2010; Rhinard 2009). This is particularly true in Europe, given the high levels of political and economic integration within the EU. As an answer to the challenges posed by TBCs, the EU has progressively developed 'European' capacities to deal with the potential effects of transboundary threats (Boin et al. 2014; Backman and Rhinard, 2017). However, prime examples like the 2015 refugee crisis or the 2008 financial crisis show that, in many cases, these episodes did not produce a systematic institutional strategy but rather fragmented answers (Authors). In fact, 't Hart and Sundelius (2013: 445) explain that 'the hardest obstacles to overcome for a whole-of-society approach (in the EU) to societal security are not so much economic or ideological, but rather institutional'. The difficulties to generate functional pressure for joint action in different policy sectors in Europe have resulted in fragmented and slow responses to particular challenges (e.g. migration, public health, the banking system) (Rhinard 2009).

In this line, some researchers have tried to understand the relationship between crises in the EU and the creation of crisis management instruments (Backman and Rinhard 2017; Boin and Rhinard 2008). Against this backdrop, how EAs fit into the overall governance 
of crises in Europe is still an open question. As some scholars have pointed out, the agencification of public administration has reconfigured the EU executive power (Coen and Thatcher 2013; Egeberg and Trondal 2011). EAs are an institutional attempt to handle aspects of the EU integration process that require considerable organizational resources (Eberlein and Grande 2005; Rittberger and Wonka 2011; Williams 2005). Although EAs have received much scholarly attention from the EU governance literature, their role in TBC management remains underexplored. Instead, the focus has been on their creation (e.g. Christensen and Nielsen 2010), the political and functional motivations behind their design (e.g. Coen and Thatcher 2008; Dehousse 2008; Eberlein and Grande 2005; LeviFaur 2011; Majone 2000 2001), how formally or de facto independent they are from other political institutions and national governments (e.g. Christensen and Laegreid 2006; Groenleer 2009; Trondal and Peters 2013; Wonka and Rittberger 2010), and how accountable they are to their political principals (Busuioc 2013, Font 2015). As new crises emerge, agencies may develop crisis management capacities depending on multiple variables that we would like to examine.

As mentioned above, we are particularly interested in the role of management boards when agencies face TBCs, as these are highly relevant components in the internal governance of EAs. They are the most visible decision-making bodies within agencies. Among their functions, they make sure that EAs meet the expectations of both the EU institutions and national governments. They also approve strategic documents, lines of action, or budgets. Moreover, they can potentially shape the activity of agencies while activating accountability mechanisms through their steering and managerial responsibilities (Busuioc 2013). The relevance of management boards is also related to their composition; they involve specialists, most of whom are from EU Member States 
(mainly represented through NRAs or national ministries), representatives of European institutions (mainly the Commission), and in some cases, additional stakeholders related to a specific policy sector (Egeberg and Trondal 2011). In summary, they represent an amalgamation of different interests and act as the most visible links between the national and European levels in the policy sector where they operate (Busuioc 2012).

How board members perceive the capacity of their agencies to respond to a TBC through its decisions and coordination with the Member States and the EU institutions may reveal the role of such agencies in the governance of TBCs in different policy sectors. This is based on the belief that, when confronting crises, organizations ideally focus on the response phase, which involves making critical decisions and coordinating a joint response (Boin and Rhinard 2008; Larsson et al. 2009).

In our study, we focus on perceptions among management board members on the basis of organizational performance studies (Brewer 2006; Pandey and Rainey 2006; Wright 2004; Rainey and Jung 2015), which argue that 'organization theory, practice, and research must consider employee (usually managerial) perceptions in any assessment of organizational performance' (Stazyk and Goerdel 2011: 648). Managerial perceptions may differ and be influenced by external political influence, 'an individual manager's personal dispositions and attitudes, organization structure, communication processes, and other factors' (Pandey and Rainey 2006: 86). They may reveal organizational attitudes, strategies and realities. Although EA management board members may have other institutional affiliations, loyalty and trust — which is part of the collective membership of groups — should be assumed (Makhashvili and Stephenson 2013). We expect that looking at perceptions among members will offer a glimpse into the dilemmas that agencies face 
when getting involved in crisis responses. This study focuses on management board perceptions on the following capacities of agencies throughout crisis responses: decisionmaking, coordination and resources.

Decision-making refers to the capacity to decide on the best response to a TBC inside the organization. According to Simon (1997), every organization needs clear procedures that facilitate rapid and informed decision-making. Hence, we assume that decision-making involves assessing the information at hand, suggesting different options, and putting forward possible scenarios. According to Cabanne and Lodge (2017: 18), organizations within policy regimes have the capacity to decide on the information they gather (i.e. riskbased strategies), the decision-making rules, and the behavior of other organizations. We also assume that a clear decision-making system implies that agencies develop protocols to be activated when confronted with crises or have flexible organizational strategies that allow for decisions to be made in the absence of such protocols. Hence, effective decisionmaking within an agency means that resources can be devoted to finding a common solution to an issue (Boin et al. 2005). For instance, when EFSA (Annex 1) was confronted with the E. coli outbreak in 2011, it already had a protocol in place for the different decisions that the scientific team had to make in order to assess the risk and present possible scenarios to EU authorities and the Member States. Conversely, when the ECDC was invited to participate in the response to the Ebola outbreak in Sub-Saharan Africa, it had to base its reply to this request on technical grounds (Authors).

Coordination is connected with decision-making and is a key component of effective responses to TBCs (Boin et al. 2014; 't Hart, et al. 1993; Heims 2016; Kettl 2003). It implies having different actors (e.g. public and private organizations, international 
partners) with different motivations and resources acting coherently in pursuit of solutions (Ansell et al. 2010). Coordinating crisis responses refers to the mechanisms that facilitate exchanging information and identifying common areas for cooperation while settling potential conflicts within networks of interdependent actors (Jordan and Schout 2006). Unlike decision-making within an EA, coordination entails actions that are decided on and implemented in conjunction with actors who are not part of the agency. For instance, coordinating with different national health authorities during the $2011 \mathrm{E}$. coli outbreak in Germany and France helped EFSA find the pathogen which had infected 3,950 people and killed 53 .

The availability of resources to respond to a crisis is a crosscutting dimension that affects agency decision-making and coordination. This dimension refers to perceiving that agencies have access to the technical, human or financial resources that they deem central to an effective response to a given TBC (Authors). This dimension is particularly relevant for EU agencies, as they may rely on other actors (e.g. the Member States) to obtain the available resources to deal with the impact of a rapidly evolving threat (Boin and Ekengren 2009; Boin et al. 2014).

\section{Examining variations in perceptions regarding agency TBC management}

We examine perceptions among EA board members regarding the involvement of their agencies in TBCs, focusing on two theoretical perspectives: the functional logic and the political-institutional approach. The functionalist argument explores how delegation benefits the decision-making process at the EU level (Majone 1996; Sandholtz and Stone 
Sweet 2010). From this perspective, many authors suggested that the emergence of agencies is an answer to the coordination dilemma within the EU governance system (Eberlein and Grande 2005; Maher, 2009; Sabel and Zeitlin 2010; Levi-Faur 2011). In contrast, the political-institutional argument claims that the design of EU agencies was driven not just by functional but also by political considerations related to distributional conflicts (Rittberger and Wonka 2013). For each logic, we identify two sets of possible explanatory factors and present the corresponding hypotheses based on the structural configuration of the agency and attributes of board members.

The nature of the agency: regulatory versus nonregulatory agencies

Some scholars working on agencification describe the functional characteristics of EAs as being a central component in determining their scope of action (e.g. Heims 2016). For example, Trondal (2010: 151) argues that agencies can be divided into three groups according to their formal powers: 'those offering advice, those carrying out inspections, and those adopting legally binding individual decisions', suggesting that their power derives from sector-specific requirements linked to a functional logic. In a similar vein, Chiti (2013) offers a threefold typology that divides EAs into those that provide information, those that coordinate common systems, and those with genuine decisionmaking powers. All in all, there is an agreement that EAs can be functionally classified according to their primary tasks into informative agencies, operational-management agencies, and (quasi) regulatory agencies (Busuioc 2013). Since (quasi) regulatory agencies are the most powerful EAs due to their binding powers and functional pressures in the sectors they operate, we expect that their board members would be more likely to perceive them as performing effectively in the management of a crisis. In particular, we 
argue that (quasi) regulatory EA officials will be more likely to perceive their agency decision-making and coordination as effective, and to perceive that such EAs have the necessary resources to deal with a transboundary crisis. Accordingly, our first hypothesis holds that:

Hypothesis 1: Management board members belonging to agencies with (quasi) regulatory powers will be more prone to perceiving decision-making (H1a) and coordination (H1b) within their agencies as effective, and to perceiving that such EAs have the necessary resources $(\mathrm{H} 1 \mathrm{c})$ to respond to transboundary crises than those belonging to agencies without binding powers.

The nature of the sector: risk-oriented agencies

A second measure of the functional logic concerning EA involvement in TBCs is related to its risk-oriented nature. Risk is very much related to identifying the chances of adverse situations arising and the potential harm that these situations may cause (Scott 2017: 24). How to regulate risks has been a matter of interest for scholars focusing on the role of organizations (Rimkuté 2018; Scott 2017; Weimer 2017). There is a general agreement that risk regulation is a 'set of rules of about which risks to accept and what measures need to be taken to minimize those risks' (Alemanno 2016: 196). From here, we can distinguish two main regulatory categories: social, which refers to health, safety, environmental, and consumer protection; and economic regulation, which refers mainly to industries with monopolistic tendencies. However, risk regulation has traditionally tended to place the latter activities into the social category (Alemanno 2016; Smismans 2017). In the case of EAs, scholars argue that some were created with the aim of 
regulating risks that may appear in specific policy sectors as a functional need to respond to massive risks - these were the cases of ECDC, EFSA, or EMSA (Rhinard 2009). Permanend and Vos (2010) have extensively argued that EFSA was created to assess food-related risks in the EU after the 1996 and 2000 'mad cow disease' crises in the UK, and that the EAs in the finance sector were created in the aftermath of the global financial crisis of the late 2000s. In a study on risk regulation and organizational reputation, Rimkuté (2018: 73) argues that those agencies 'involved in risk governance are expected to perform distinct tasks compared to other organizations in the polity' because they are more likely to base their risk assessment activities 'on technical evidence and sciencebased judgements conducted by impartial (scientific) experts in the field'. We argue that the board members of the EAs that have been formally designed to respond to risks will be more likely to perceive their agency decision-making and coordination as effective, and to perceive that such agencies have the resources to respond to a transboundary crisis than those who belong to non-risk-oriented agencies.

Hypothesis 2: Management board members belonging to risk-oriented agencies will be more prone to perceiving decision-making $(\mathrm{H} 2 \mathrm{a})$ and coordination $(\mathrm{H} 2 \mathrm{~b})$ within their agencies as effective, and to perceive that such agencies have the necessary resources $(\mathrm{H} 2 \mathrm{c})$ to respond to transboundary crises than board members serving in agencies that do not focus on risk-oriented activities.

Personal profile: educational qualifications of board members

Some scholars have argued that the existence of EAs has been justified on functional grounds, namely that apolitical and expert knowledge guide their decisions in diverse 
policy sectors (Thatcher 2011; Rittberger and Wonka 2013). Expert knowledge in organizations has been assumed to be desirable since, as Christensen et al. (2017: 453) argue, the 'specialized expertise of officials', which can be 'defined through the possession of higher educational qualifications based on specialized training ... constitutes one important aspect of an efficient public administration.' Studies on organizational culture in public and private organizations have linked educational attainment with the capacity to adapt to organizational change (Cordery et al. 1993; Iverson 1996). For instance, Cordery et al. (1993) identified that the educational attainment of public officials in Australia influenced their acceptance of organizational change. Similarly, studies on private organizations have focused on the educational level of managers to explain adaptability to and acceptance of changes within firms (Bantel and Jackson 1989; Barker and Mueller, 2002; Finkelstein and Hambrick, 1996). From this perspective, educational level may serve as a proxy to identify the development of human capital, knowledge base and intellectual competence within an organization (Barro and Lee 2010; Wailderdsak and Suehiro 2004). On this basis, from a functional logic, we expect that the educational qualification of board members will positively affect their perceptions on the capacities of EAs to make decisions and coordinate effectively during a crisis, as well as on their capacity to gain access to the necessary resources to respond to them.

Hypothesis 3: Management board members with higher levels of education will be more prone to perceiving decision-making $(\mathrm{H} 3 \mathrm{a})$ and coordination $(\mathrm{H} 3 \mathrm{~b})$ within their agencies as effective, and to perceiving that such agencies have the necessary resources $(\mathrm{H} 3 \mathrm{c})$ to respond to crises than those members with lower educational qualifications. 
Some authors have suggested that the emergence of EAs was an institutional response to a need for policy coordination within the EU governance system (Eberlein and Grande 2005; Levi-Faur 2011; Majone 1997; Sabel and Zeitlin 2010). From this logic, EAs can be seen as the outcome of a consensus to endow EU institutions with specialized bodies to harmonize the rules and offer credible information on specific policy areas. If the same logic is applied to explain EA behavior during TBCs, then it might be expected that the existence of consensus among key institutional actors, such as the Member States and EU institutions, would trigger a greater involvement of agencies in TBCs. Thus, if board members also adopt this logic, we might expect that they will perceive decision-making and coordination within their agencies as effective, and consider that such agencies have the necessary resources to respond to TBCs when there is consensus among key actors on its response.

Hypothesis 4: If board members perceive that key actors agree on how to respond to crises, they will be more likely to perceive decision-making (H4a) and coordination (H4b) within their agencies as effective, and that such agencies have the necessary resources $(\mathrm{H} 4 \mathrm{c})$ to respond to TBCs than those who perceive disagreement among key actors on this matter. 


\section{Perceptions among board members regarding crisis management}

\section{Data}

The empirical analysis in our study is based on two original sources: the first is an online survey of perceptions among EA management board members regarding TBC management; the second consists of an original biographical database of these board members. The online survey was distributed among management board members of 30 EAs. The survey included four sections. The first section assessed the decision-making capacity of agencies when facing TBCs, the second examined their coordination capacity, the third their communication capacity, and the fourth looked at their direct involvement in crisis management. After three reminders, we obtained 162 responses from board members of 27 out of the 30 EAs surveyed (an overall response rate of $18.8 \%)^{1}: 0.6 \%$ of respondents had been appointed by the European Parliament, $2.4 \%$ by the Commission, $6.1 \%$ by the Council, $78.2 \%$ by the Member States, and $10.3 \%$ by stakeholders. The survey was submitted to 887 of the 947 board members that were included in the sample -we were unable to reach 60 board members due to missing contact information (for more on the response rate, see Annex 2). Two other agencies (EUROJUST and OSHA) were not included in the survey, as they did not agree to participate. Furthermore, we did not include agencies under the Common Security and Defence Policy (Satcen, EDA, and EUISS) or the CdT, given that the latter body serves other EU institutions through translation work. We also excluded two agencies from the analysis, as we did not obtain

\footnotetext{
${ }^{1}$ Since we collected biographical data on 887 board members serving in 27 EAs, we were able to investigate the representativeness of our response rate. To do so, we followed the recommendations of Knoef and de Vos (2009), who suggest comparing the characteristics of the survey respondents with statistics that refer to the total population of board members. For example, they suggest comparing the educational degree of our respondents with statistics that refer to the population of board members. In addition, to test whether these differences are significant or not, we carried out significance tests. In particular, we tested for over- and underrepresentation with Chi-square analyses.
} 
any responses from them (ESMA and SRB). In addition, we also collected biographical data on the board members surveyed across 27 EAs. This information was collected from agency websites, online CVs, LinkedIn, and the websites of their primary employers.

This article examines two dependent variables: perceived effectiveness in decisionmaking and coordination. Additionally, we included in our analysis a third dependent variable which is the perceived availability of resources to contribute effectively to TBC responses. We measured the first two variables on the basis of the following questions: (a) How effective do you consider the agency decision-making to be during a TBC? and (b) How effective do you consider the agency to be at coordinating different players during a crisis? In order to capture the degree to which board members believe that their respective EAs have the necessary resources to respond to a crisis, we used the following question: (c) In your opinion, does your agency have the necessary resources to respond to a crisis on its own? The distribution of responses is shown in Figure 1 (detailed responses across agencies are shown in Annex 2). 
Figure 1. Board members perceptions in EAS
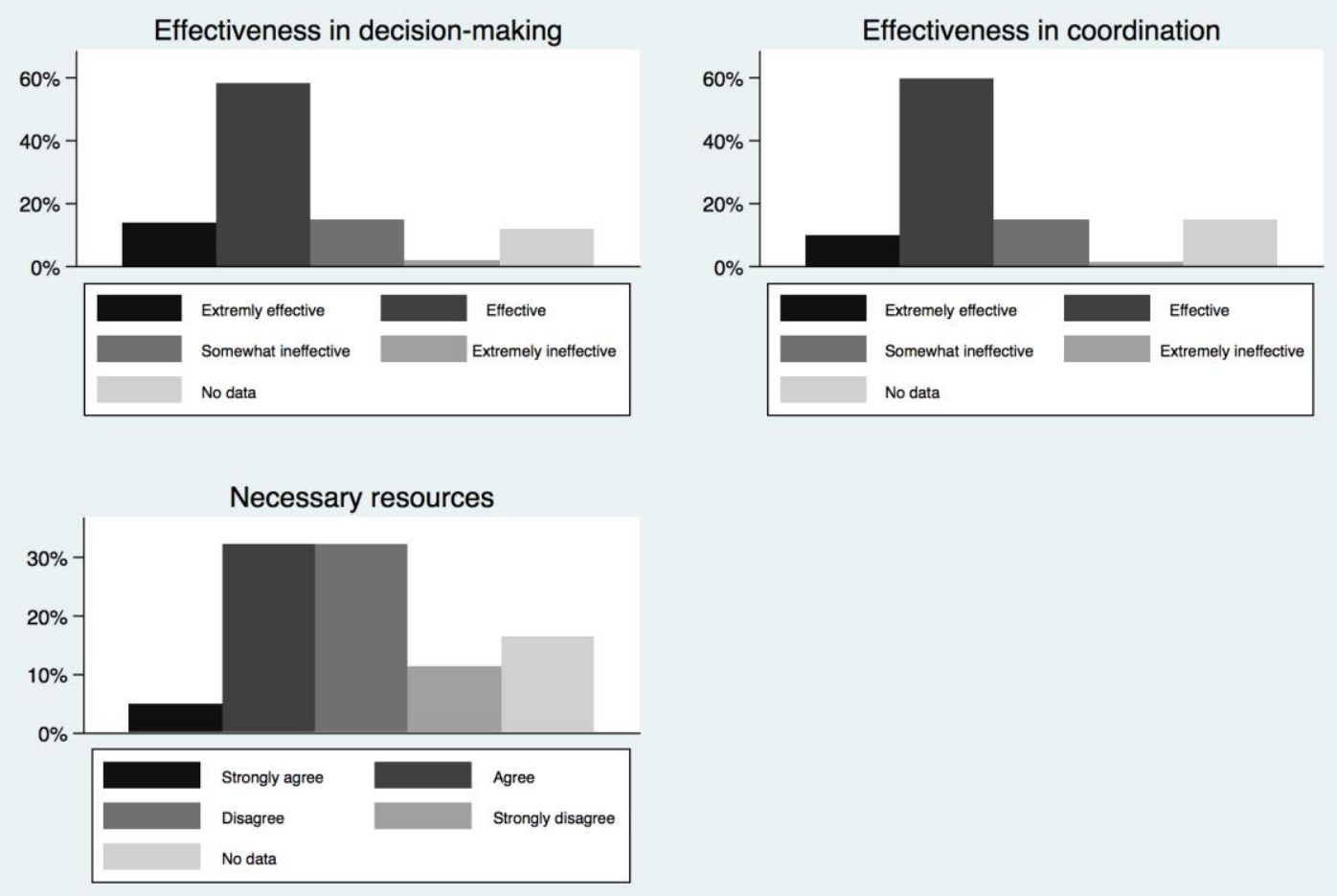

Since the number of observations is small, we recoded these categorical variables into dummies, where 1 corresponds to a positive assessment concerning the performance of the agency. In the first two variables, we assigned 1 for every response that fell under "extremely effective" / "effective", and 0 for those that fell under "extremely ineffective" and "somewhat ineffective". In the third variable, we assigned 1 for every response that fell under "strongly agree" / "agree", and 0 for those under "disagree" / "strongly disagree".

To test our first hypothesis, that regarding the attitudes of members belonging to agencies with regulatory powers versus those that do not, we used the classification of EAs developed by Busuioc (2013). In particular, we used a binary variable showing (1) for every board member that belonged to an agency that carried out regulatory tasks and (0) for those that belonged to agencies that did not. For the second hypothesis, that regarding the perceptions of members belonging to agencies with social risk assessment mandates, 
we used a binary variable indicating members from agencies that did include these provisions in their founding regulations (1) versus members from agencies with no legal provisions on the subject (0). We classified eight agencies as having this profile: EASA, EFSA, EMA, EMSA, ENISA, ECHA, ECDC, and EMCDDA. For example, the founding documents of EFSA, EMA, ECHA, ECDC, and EMCDDA clearly specify that one of the central objectives of these agencies is to deal with potential risks to public health. To test our third hypothesis on the educational qualifications of board members, we used a binary variable indicating whether each management board member included in the analysis had been awarded a $\mathrm{PhD}(1)$ or not (0). To test our fourth hypothesis about political logic, we used the following question from our survey: How much do you agree with the following statement? The messages issued by the agency to explain the causes of a crisis are accepted by the other relevant players involved (e.g. the European Commission, the European Parliament, the Council, national agencies, and national governments). We used this question as a proxy that indicates whether relevant policy players agree on how to manage a crisis. Specifically, we created a dummy variable indicating whether board members "strongly agree" / "agree" (1) or "strongly disagree" / "disagree" (0).

\section{Analysis and results}

To examine the effects of the above-mentioned agency characteristics and professional attributes of board members, we used logistic regression models clustered by agency. Since we ran clustered models, our analysis included EAs from which we obtained at least two responses: it is worth noting that the regression analysis did not include EIOPA and GSA since we only obtained one response from these agencies. With the aim to provide a more robust analysis, we also excluded those agencies whose response rate was 
lower than $15 \%$ (see Annex 2), representing an overall response rate of $20 \%$. The main results are reported in Table 1 (descriptive statistics are shown in Annex 3). To assess the robustness of our results, we carried out the analysis by including only those agencies that achieved a response rate that was higher than $20 \%$ (see Annex 4), representing an overall response rate of $21 \%$. The findings from these robustness tests support the following results (see Table 1).

Table 1. Logistic regression for perceived effectiveness in decision-making and coordination, as well as availability of resources to face transboundary crises

\begin{tabular}{lccc}
\hline & $\begin{array}{c}\text { Effectiveness } \\
\text { Decision making }\end{array}$ & $\begin{array}{c}\text { Effectiveness } \\
\text { Coordination }\end{array}$ & $\begin{array}{c}\text { Necessary } \\
\text { Resources }\end{array}$ \\
\hline Regulatory agencies & $-0.66 .$. & $-0.26 .$. & $2.206^{* * *}$ \\
Risk profile agencies & $(0.63)$ & $(0.61)$ & $(0.38)$ \\
& $-0.73 .$. & $-1.161^{* *}$ & $0.19 .$. \\
PhD degree & $(0.62)$ & $(0.59)$ & $(0.38)$ \\
& $0.59 .$. & $0.37 .$. & $0.67 .$. \\
Causes accepted & $(0.55)$ & $(0.62)$ & $(0.48)$ \\
Relevant players & $2.015^{* * *}$ & $1.52^{* * *}$ & $0.50 .$. \\
& & & $(0.48)$ \\
Constant & $(0.36)$ & $(0.51)$ & $-2.18^{* * *}$ \\
& 0.51. & 1.11 & $(0.55)$ \\
Observations & $(0.75)$ & $(0.80)$ & 90 \\
Clusters & 94 & 94 & 17 \\
Pseudo R & 17 & 17 & 0.20 \\
AIC & 0.16 & 0.11 & 107.888 \\
\hline
\end{tabular}

Note: Numbers in parentheses represent standard errors. Significant at $* \mathrm{p} \leq .10 ; * * \mathrm{p} \leq$ $.05 ; * * * \mathrm{p} \leq .01$

Note: agencies with a response rate $>15 \%$

Regarding perceptions on effective decision-making, our findings provide some evidence supporting our theoretical expectation in $\mathrm{H} 4 \mathrm{a}$. Board members who consider that there is 
a high level of agreement among relevant players on the causes of a crisis are more likely to perceive their agencies as institutions with an effective decision-making process. We also identify that the predicted probability — holding all other variables at their modesof perceived effectiveness in decision-making is 0.93 when board members perceive a high level of agreement, in contrast to 0.62 in those who do not perceive such level of agreement. A similar result is obtained when we examine effectiveness in coordination (H4b), which also suggests that perceptions of consensus on the causes of a crisis among board members not only affect their views on strategic decision-making inside the agency but also on the operationalization of the response with other players. The predicted probability is 0.93 . One possible interpretation is that they believe that only in the presence of a common understanding of the crisis, the agency might be seen as more necessary for decision-making and coordination. Actually, since political principals have not fully delegated powers to them, EAs might be unable to exert leadership during TBCs on the sole basis of their formal powers, unless some political consensus supporting their mandate is present.

Our analysis also provides evidence that board members belonging to risk-profile agencies are less likely to perceive their respective agencies as effective contributors to the coordination process during crises than members working in non-risk profile agencies (H2b). We identify that the predicted probability — holding all other variables at their modes - of perceived effectiveness in coordination in the case of risk profile agencies is 0.81 , while this figure amounts to 0.93 when it comes to non-risk profile agencies. One possible interpretation is that, since coordination requires interactions with actors that are not part of the agency, the agencies may find difficulties to fully use their risk-assessment or management tools when confronting crises. Perceptions of board members might be 
influenced by the perceived low linkages among the different players within the policy sector where the agency operates.

Finally, our analysis suggests that board members who belong to (quasi) regulatory agencies are more likely to perceive that their respective agencies have the necessary resources to respond to a crisis than those members working in operational or informative agencies. This finding is in line with our theoretical expectation that board members belonging to agencies with the power to set out binding standards are more likely to perceive that their EAs have the necessary resources to deal with TBCs (H1c). In particular, the predicted probability - holding all other variables at their modes - of perceiving that their EAs have such resources is 0.63 in the case of board members who belong to (quasi) regulatory agencies, in contrast to 0.16 when it comes to those who belong to informative / operational agencies. In favor of this, it is important to recall that the resources required for effective regulatory interventions during a crisis are not comparable to the resources needed in most agencies focused on policy distribution or redistribution. Contrary to our theoretical expectations, we did not find any association between higher degrees of scientific specialization and perceptions on agency involvement in the management of TBCs.

\section{Describing the role of political actors}

Since we identified in the previous section a relationship between perceptions of political consensus among key actors and the capacity of agencies to exercise decision-making and coordination, a better understanding of who these players are is needed. In this 
section, we describe the perceptions of board members regarding the role of important players in decision-making and coordination during crises. In particular, we paid attention to perceptions attributed to the European Commission, national regulatory agencies (NRAs), and national governments. We identified that our respondents differed in terms of the importance attributed to specific players in agency decision-making processes during a TBC. For example, the Commission was seen as being either important or extremely important when the agency is confronted with a crisis $(85 \%)$. This figure amounts to $78 \%$ both in the cases of NRAs and national governments. Conversely, business associations and civil society organizations (CSOs) were assessed as being much less important by respondents ( $49 \%$ believed the former to be important or extremely important, while only $48 \%$ said this of the latter). See Table 2.

Table 2. To what extent are the following players important in agency decision-making during a transboundary crisis?

\begin{tabular}{|l|c|c|c|c|c|c|c|}
\hline & $\begin{array}{c}\text { Business } \\
(\%)\end{array}$ & $\begin{array}{c}\text { National } \\
\text { Agencies } \\
(\%)\end{array}$ & $\begin{array}{c}\text { Council } \\
(\%)\end{array}$ & $\begin{array}{c}\text { EC } \\
(\%)\end{array}$ & $\begin{array}{c}\text { EP } \\
(\%)\end{array}$ & $\begin{array}{c}\text { CSOs } \\
(\%)\end{array}$ & $\begin{array}{c}\text { National } \\
\text { Governments } \\
(\%)\end{array}$ \\
\hline $\begin{array}{l}\text { Extremely } \\
\text { Important/ } \\
\text { Important }\end{array}$ & 48.79 & 78.05 & 65.86 & 84.76 & 58.53 & 48.17 & 78.05 \\
\hline $\begin{array}{l}\text { Somewhat } \\
\text { Important/ } \\
\text { Not at all }\end{array}$ & 48.17 & 20.12 & 29.27 & 10.98 & 35.36 & 46.35 & 16.46 \\
\hline & 3.05 & 1.83 & 4.88 & 4.27 & 6.10 & 5.49 & 5.49 \\
\hline
\end{tabular}

Similar to our findings regarding decision-making, a high percentage of respondents considered NRAs $(75 \%)$ and the Commission $(73 \%)$ to be important or extremely important in coordinating players during a TBC, while national governments remain below the former two (70\%). This is probably because this dimension involves more 
technically complex procedures. On the other hand, social actors such as CSOs and business associations were only considered to be important or extremely important by $40 \%$ and $44 \%$ of respondents, respectively, whereas $40 \%$ of respondents considered this to be true of the European Parliament (see Table 3). In general, our study shows that throughout crises only the Commission and the Member States are perceived by EA board members to be of utmost importance, without attributing greater relevance to any of these over the other. This finding also supports the idea that dual perceptions of their hierarchical dependence coexist in agency processes, at least when it comes to board member views.

Table 3. How important are the following players in coordinating different tasks related to TBC management (e.g., detecting a threat, gathering information, communicating information, implementing actions)?

\begin{tabular}{|c|c|c|c|c|c|c|c|}
\hline & $\begin{array}{c}\text { Business } \\
(\%)\end{array}$ & $\begin{array}{c}\text { National } \\
\text { Agencies } \\
(\%)\end{array}$ & $\begin{array}{c}\text { Council } \\
(\%)\end{array}$ & $\begin{array}{c}\text { EC } \\
(\%)\end{array}$ & $\begin{array}{c}\text { EP } \\
(\%)\end{array}$ & $\begin{array}{c}\text { CSOs } \\
(\%)\end{array}$ & $\begin{array}{c}\text { National } \\
\text { Governments } \\
(\%)\end{array}$ \\
\hline $\begin{array}{c}\text { Extremely } \\
\text { Important/ } \\
\text { Important }\end{array}$ & 43.56 & 75.46 & 52.15 & 73.01 & 39.88 & 39.88 & 69.94 \\
\hline $\begin{array}{c}\text { Somewhat } \\
\text { Important/ Not } \\
\text { at all } \\
\text { Important }\end{array}$ & 41.10 & 11.04 & 33.13 & 14.73 & 45.40 & 44.79 & 16.57 \\
\hline N/A & 15.34 & 13.50 & 14.72 & 12.27 & 14.72 & 15.34 & 13.50 \\
\hline
\end{tabular}




\section{Conclusions}

The last two decades have brought growth in the number and size of challenges faced by the European Union. We have moved from an initial stage when the European project was still being constructed to one of consolidation. However, multiple challenges of a financial, socio-political, environmental and technological nature are proving to be new sources of TBCs. Since 2008, the financial crisis has called the whole Euro-currency project into question; for their part, the growth of a disruptive political rhetoric and the refugee crisis also seem to be posing immediate challenges to Europe. It is important to understand how European institutions should cope with them and the different options that are part of the EU remedial repository. In this context, our study examined the perceptions of key players within EAs, namely their management board members. In particular, we focused on their opinions regarding the capacities of agencies to handle crucial aspects of TBCs: decision-making, coordination, as well as the availability of the necessary resources to face a crisis.

We examined the role of four variables that may affect board member perceptions regarding the capacity of agencies to respond to TBCs. First, we identified that board members belonging to risk-profile agencies are -in comparison to those working in nonrisk profile agencies- more likely to perceive their respective agencies as less effective when it comes to coordination. We believe that the agencies might find challenges to offer coherence in this crucial aspect of the response, since coordination implies interacting with actors that are not part of the agency. Secondly, we found that board members belonging to (quasi) regulatory agencies are - in comparison to those working in nonregulatory agencies - more likely to perceive that their respective agencies have the necessary resources to contribute effectively to a crisis response. Both cases show that 
management board members do not perceive their agencies as crisis-solving institutional devices; on the contrary, they perceive that agencies have some difficulties to respond to TBCs.

In connection with the political logic and in line with other academic work on agencification (e.g. Boin et al. 2014; Thatcher 2011), our study also examined whether board member perceptions of consensus among key decision-makers in Europe —or the absence thereof - regarding the causes of crises may affect how board members perceive the role of the agency during a TBC. We found that when views on the matter coincide, board members might perceive the contribution of an agency - both during the decisionmaking and the coordination processes - as more necessary to solve the crisis. In other words, our respondents clearly accepted the idea that EAs should be involved in solving TBCs, but only if consensus among relevant EU actors existed and the agency received a clear mandate for this purpose. Moreover, they did not portray the agency as an autonomous actor struggling with others to receive more responsibilities or to become a leader in the management of the crisis.

Furthermore, we assessed the importance that board members gave to different political principals. The findings showed that board members attributed more importance to the European Commission, NRAs, and national governments. These findings allow us to conclude that board members perceive the power-sharing between the Member States and the European Commission as a reflection of the agency independence. We confirmed that EAs work as specialized policy hubs where both EU institutions and national governments are capable of articulating their collaboration when necessary. This also suggests that board members perceive EAs behavior throughout TBCs as potentially 
moving beyond intergovernmental cooperation. That is, under severe constraints, a political consensus on how to address crises emerges among major actors.

The study of TBCs through the perceptions of EA board members shows how the 'problems of fragmentation, sectoralization and policy interdependence so commonly seen along the EU institutions and member states' (Peters and Wright 2001: 58) are being overcome. However, future research on the role of agencies in crisis management should also examine the attitudes of the staff members who are involved in the day-to-day running of the agency (e.g. directors, scientific members, experts). This would expand our knowledge and understanding concerning the involvement of agencies in different crises, allowing us to observe whether pressures for agency leadership in TBCs emerge also from within. Moreover, further analyses would also benefit from studying perceptions among board and staff members of crisis management according to the policy sector where agencies operate. The effectiveness of an agency depends not just on the decisions made by the board or the resources at its disposal, but also on external factors related to the different characteristics of the sector within which it operates. Ultimately, future research should contribute to a better and deeper understanding of the potential and limitations of agencies to respond to the emerging threats that Europe is facing in different areas. 


\section{References}

Alemanno, Alberto (2016). "Risk and Regulation." In: A. Burgess, A. Alemanno and J. Zinn (eds.). Routledge Handbook of Risk Studies. London: Routledge.

Ansell, Chris, Arjen Boin, and Anne Keller (2010). "Managing Transboundary Crises: Identifying the Building Blocks of an Effective Response System." Journal of Contingencies and Crisis Management, 18(4), 195-207.

Backman, Sarah and Mark Rhinard (2018). "The European Union's capacities for managing crises." Journal of Contingencies and Crisis Management, 26(2), 261271.

Bantel, Karen and Susan Jackson (1989), "Top management and innovations in banking: does the composition of the top team make a difference?" Strategic Management Journal, 10(S1), 107-124.

Barker III, Vincent and George Mueller (2002). "CEO characteristics and firm R\&D spending", Management Science, 48(6), 782-801.

Blauberger, Michael and Berndt Rittberger (2015). "Conceptualising and Theorising EU Regulatory Networks." Regulation and Governance, 9(4), 367-376.

Boin, Arjen, Paul 't Hart, Eric Stern and Bengt Sundelius (2005). The politics of crisis management: Public leadership under pressure. Cambridge: Cambridge University Press.

Boin, Arjen and Mark Rhinard. (2008). "Managing Transboundary Crises: What Role for the European Union?” International Studies Review, 10(1), 1-26.

Boin, Arjen, and Magnus Ekengren (2009). "Preparing for the world risk society: Towards a new security paradigm for the European Union." Journal of Contingencies and Crisis Management 17(4): 285-294.

Boin, Arjen, Madalina Busuioc, and Martjin Groenleer (2014). "Building European Union Capacity to Manage Transboundary Crises: Network or Lead-Agency Model?" Regulation \& governance, 8(4), 418-436.

Boin, Arjen, Lavinia Cadar and Maureen Donnelley (2015). "D2.1. Analytical Framework: Understanding Transboundary Crisis Management: A Theoretical Framework." Deliverable for the Transcrisis project. CrisisPlan.

Brewer, Gene (2006). "All measures of performance are subjective: More evidence on U.S. federal agencies.” In: G. Boyne; J. Kenneth; L. Meier; Jr. O’Toole and R.M. Walker (eds), Public services performance: Perspectives on measurement and management. Cambridge: Cambridge University.

Busuioc, Madalina (2012). "European Agencies and Their Boards: Promises and Pitfalls of Accountability beyond Design." Journal of European Public Policy, 19(5), 719-736.

Busuioc, Madalina (2013). European Agencies: Law and Practices of Accountability, Oxford: Oxford University Press.

Busuioc, Madalina and Martin Lodge (2016). "The Reputational Basis of Public Accountability". Governance, 29(2), 247-263.

Cabanne Lydie and Martin Lodge (2017). "Summary of the research findings in the four regimes." Deliverable for the Transcrisis project. London School of Economics, available at: http:// https://www.transcrisis.eu/wp-content/uploads/2017/08/D5.1European-Government-of-Crisis.pdf

Chiti, Edoardo (2013). "European Agencies' Rulemaking: Powers, Procedures and Assessment.” European Law Journal, 19(1), 93-110. 
Christensen, Tom and Per Lægreid (Eds.). (2006). Autonomy and Regulation: Coping with Agencies in the Modern State. Edward Elgar Publishing.

Christensen, Jorgen and Vibeke Nielsen (2010). "Administrative Capacity, Structural Choice and the Creation of EU Agencies." Journal of European Public Policy 17(2), 176-204.

Christensen, Johan, Petra van den Bekerom and Joris van der Voet (2017). "Representative Bureaucracy and Specialist Knowledge in the European Commission." Public Administration, 95 (2), 450-467.

Coen, David and Mark Thatcher (2008). "Network Governance and Multilevel Delegation: European Networks of Regulatory Agencies." Journal of Public Policy 28(1), 49-71.

Cordery, John, Peter Sevastos, Wally Mueller and Sharon Parker (1993). "Correlates of employee attitudes toward functional flexibility." Human Relations, 46, 705-23

Dehousse, Renaud (2008). "Delegation of Powers in the European Union: The Need for a Multi-Principals Model." West European Politics, 31 (Four), 789-805.

Eberlein, Burkard, and Edgar Grande (2005). "Beyond Delegation: Transnational Regulatory Regimes and the EU Regulatory State." Journal of European Public Policy, 12(1), 89-112.

Egeberg, Morten and Jarle Trondal (2011). "EU-level agencies: new executive centre formation or vehicles for national control?" Journal of European Public Policy, 18(6), 868-887.

Finkelstein, Sidney and Donald Hambrick (1996). Strategic Leadership: Top Executives and Their Effects on Organizations, St Paul: West Publishing Company.

Font, Nuria (2015). "Informal Rules and Institutional Balances on the Boards of EU Agencies." Administration and Society, DOI: 10.1177/0095399715588782.

Groenleer, Martjin (2009). The Autonomy of European Union Agencies: A Comparative Study of Institutional Development, Delft: Eburon Uitgeverij.

't Hart, Paul, Uriel Rosenthal and Alexander Kouzmin (1993). "Crisis Decision Making: The Centralization Thesis Revisited." Administration and Society, 25(1), 12-45.

't Hart, Paul and Bengt Sundelius (2013). "Crisis management revisited: A new agenda for research, training and capacity building within Europe." Cooperation and Conflict, 48(3), 444-461.

Heims, Eva (2016). "Explaining Coordination between National Regulators in EU Agencies: The Role of Formal and Informal Social Organization." Public Administration, 94(4), 881-896.

Iverson, Roderick (1996). "Employee acceptance of organizational change: the role of organizational commitment." The International Journal of Human Resource Management, 7: 122-49.

Jordan, Aandrew and Adriaan Schout (2006). The Coordination of the European Union: Exploring the Capacities of Networked Governance, Oxford: Oxford University Press.

Kelemen, Daniel, and Andrew Tarrant (2011). 'The Political Foundations of the Eurocracy'. West European Politics, 34(5): 922-947.

Kettl, Donald (2003). System under stress: Homeland security and American politics. Washington, DC: CQ Press.

Knoef, Marike, and Klaas de Vos. (2009). "The representativeness of LISS, an online probability panel" (Working paper). CentERdata, Tilburg University. Retrieved from http://www.lissdata.nl/lissdata/About the_Panel/Composition_\&_Response 
Larsson, Per, Eva Hagström Frisell, and Stefan Olsson (2009). "Understanding the crisis management system of the European Union." In: S. Olsson (ed.). Crisis Management in the European Union. Berlin, Heidelberg: Springer.

Levi-Faur, David (2011). "Regulatory Networks and Regulatory Agencification: Towards a Single European Regulatory Space." Journal of European Public Policy, 18(6), 810-829.

Maher, Imelda (2009). "Functional and normative delegation to non-majoritarian institutions: The case of the European Competition Network." Comparative European Politics, 7(4): 414-434.

Majone, Giandomenico (1996). Regulating Europe, London: Routledge.

Majone, Giandomenico (1997). From the Positive to the Regulatory State: Causes and Consequences of Changes in the Mode of Governance. Journal of public policy, 17 (2): 139-167.

Majone, Giandomenico (2000). The Credibility Crisis of Community Regulation. Journal of Common Market Studies, 38 (2): 273-302

Majone, Giandomenico (2001). "Nonmajoritarian institutions and the limits of democratic governance: a political transaction-cost approach." Journal of Institutional and Theoretical Economics 157, 57-78.

Makhashvili, Levan and Paul Stephenson (2013). "Differentiating agency independence: perceptions from inside the European Medicines Agency (EMA)." Journal of Contemporary European Research, 9(1): 4 - 23.

Moloney, Niamh (2010). "EU Financial Market Regulation after the Global Financial Crisis: "More Europe" or More Risks?" Common Market Law Review, 47(5), 1317-1383

Olsson, Steffan (2009). Crisis Management in the European Union-Cooperation in the Face of Emergencies, Berlin-Heidelberg: Springer

Pandey, Sanjay and Hal Rainey (2006). "Public managers' perceptions of organizational ambiguity: Analyzing alternative models." International Public Management Journal 9: 85-112.

Permanand, Govin and Ellen Vos (2010). "EU regulatory agencies and health protection." In: E. Mossialos, G. Permanand, R. Baeten and T. Hervey (eds). Health systems governance in Europe: the role of European Union law and policy. Cambridge, Cambridge.

Peters, Guy and Vincent Wright (2001). "The National Coordination of European Policy Making," in: J. Richardson (ed). European Union: Power and Policy Making, London: Routledge

Rainey, Hal and Chang Su Jung (2015). "A conceptual framework for analysis of goal ambiguity in public organizations." Journal of Public Administration Research and Theory, 25(1), 71-99.

Rhinard, Mark (2009). "European cooperation on future crises: toward a public good?" Review of policy research, 26(4), 439-455.

Rimkute, Dovilè (2018). "Organizational reputation and risk regulation: The effect of reputational threats on agency scientific outputs." Public Administration, 96(1), 70-83.

Rittberger, Berthold, and Arndt Wonka (2011). "Introduction: Agency Governance in the European Union." Journal of European Public Policy, 18(6), 780-789.

Rittberger, Berthold, and Arndt Wonka (2013). Agency Governance in the EU. London: Routledge.

Rosenthal, Uriel, Michael Charles and Paul 't Hart (eds) (1989). Coping with Crises. Charles Thomas: Springfield. 
Sabel, Charles and Jonathan Zeitlin (eds.) (2010). Experimentalist governance in the European Union: towards a new architecture. Oxford: Oxford.

Sandholtz, Wayne and Alec Stone Sweet (2012). "Neofunctionalism and Supranational Governance." In Erick. Jones, A. Menon, and S. Weatherill (eds.). The Oxford Handbook of the European Union (pp. 18-33). Oxford: Oxford University press.

Scott Colin (2017). "Regulation and Risk Today." European Journal of Risk Regulation 8 (1): 24-27.

Smismans, Stijn (2017) Risk Regulation at Risk. Brexit, Trump it, Risk it. European Journal of Risk Regulation, 8 (1): 33-42.

Stazyk, Edmund and Holly Goerdel (2011). "The Benefits of Bureaucracy: Public Managers' Perceptions of Political Support, Goal Ambiguity, and Organizational Effectiveness." Journal of Public Administration Research and Theory 21(4), 645-672.

Thatcher, Mark (2011) The Creation of European Regulatory Agencies and Its Limits: A Comparative Analysis of European Delegation. Journal of European Public Policy, 18 (6): 790-809.

Thatcher, Mark and David Coen. (2008). "Reshaping European Regulatory Space: An Evolutionary Analysis.” West European Politics, 31 (4), 806-836. Available at: https://doi.org/10.1080/01402380801906114.

Trondal, Jarle (2010) An Emergent European Executive Order. Oxford: Oxford

Trondal, Jarle and Guy Peters (2013). The rise of European administrative space: lessons learned. Journal of European Public Policy, 20 (2): 295-307.

van Ondarza, Nicolai and Roderick Parkes (2010). The EU in the Face of Disaster: Implementing the Lisbon Treaty's Solidarity Clause. SWP Comments 9, German Institute for International and Security Affairs, Berlin. Available at: https://www.swp-

berlin.org/fileadmin/contents/products/comments/2010C09_orz_pks_ks.pdf (accessed 30 November 2018).

Vos, Ellen (2000). EU Food Safety Regulation in the Aftermath of the BSE Crisis. Journal of Consumer Policy, 23 (3): 227-55.

Wailderdsak, Natenapha and Akira Suehiro (2004). "Top executive origins: comparative study between Thailand and Japan." Asian Business and Management, 3: 85-104.

Weimer, Maria (2017). The Origins of "Risk" as an Idea and the Future of Risk Regulation. European Journal of Risk Regulation 8 (1): 10-17.

Williams, Garrath (2005). "Monomaniacs or schizophrenics?: Responsible governance and the EU's independent agencies." Political Studies, 53(1), 82-99.

Wonka, Arndt and Berthold Rittberger (2010). "Credibility, Complexity and Uncertainty: Explaining the Institutional Independence of 29 EU Agencies." West European Politics, 33(4), 730-752.

Wright, Bradley (2004). "The role of work context in work motivation: A public sector application of goal and social cognitive theories." Journal of Public Administration Research and Theory 14, 59-78. 
Annex 1. List of Acronyms 
1. ACER, Agency for the Cooperation of Energy Regulators;

2. BEREC, Body of the European Regulators of Electronic Communications;

3. CEDEFOP, European Centre for the Development of Vocational Training;

4. CEPOL, European Union Agency for Law Enforcement Training;

5. CPVO, Community Plant Variety Office;

6. EASA, European Aviation Safety Agency;

7. EASO, European Asylum Support Office;

8. EBA, European Banking Authority;

9. ECDC, European Centre for Disease Prevention and Control;

10. ECHA, European Chemicals Agency;

11. EEA, European Environment Agency;

12. EFCA, European Fisheries Control Agency;

13. EFSA, European Food Safety Agency;

14. EIGE, European Institute for Gender Equality;

15. EIOPA, European Insurance and Occupational Pension Authority;

16. EMA, European Medical Agency;

17. EMCDDA, European Monitoring Centre for Drugs and Drug Addiction;

18. EMSA, European Maritime Safety Agency;

19. ENISA, European Union Agency for Network and Information Security;

20. ERA, European Rail Agency;

21. ETF, European Training Foundation;

22. EUIPO (OHIM), European Union Intellectual Property Office;

23. EU-LISA, European Agency for the Operational Management of Large-Scale IT Systems;

24. EUROFOUND, European Foundation for the Improvement of Living and Working Conditions;

25. EUROPOL, European Police Office;

26. FRA, European Agency for Fundamental Rights;

27. Frontex, European Border and Coast Guard Agency;

Annex 2. Response rate by agency 


\begin{tabular}{|c|c|c|c|c|}
\hline & $\begin{array}{c}\text { Agency } \\
\text { Acronym }\end{array}$ & $\begin{array}{c}\text { Number of MB } \\
\text { members } \\
\text { (according to } \\
\text { EAs } \\
\text { founding } \\
\text { documents) }\end{array}$ & $\begin{array}{l}\text { Number of } \\
\text { respondents } \\
\text { (after third } \\
\text { reminder) }\end{array}$ & $\begin{array}{l}\text { Response } \\
\text { rate (\%) }\end{array}$ \\
\hline 1 & ACER & 9 & 2 & $22,2 \%$ \\
\hline 2 & BEREC & 29 & 6 & $20,7 \%$ \\
\hline 3 & CEDEFOP & 89 & 18 & $20,2 \%$ \\
\hline 4 & CEPOL & 26 & 6 & $23,1 \%$ \\
\hline 5 & CPVO & 29 & 4 & $13,8 \%$ \\
\hline 6 & EASA & 33 & 4 & $12,1 \%$ \\
\hline 7 & EASO & 31 & 2 & $6,5 \%$ \\
\hline 8 & EBA & 7 & 2 & $28,6 \%$ \\
\hline 9 & ECDC & 33 & 6 & $18,2 \%$ \\
\hline 10 & $\mathrm{ECHA}$ & 36 & 8 & $22,2 \%$ \\
\hline 11 & EEA & 32 & 3 & $9,4 \%$ \\
\hline 12 & EFCA & 34 & 4 & $11,8 \%$ \\
\hline 13 & EFSA & 15 & 10 & $66,7 \%$ \\
\hline 14 & EIGE & 19 & 3 & $15,8 \%$ \\
\hline 15 & EIOPA & 7 & 1 & $14,3 \%$ \\
\hline 16 & EMA & 36 & 7 & $19,4 \%$ \\
\hline 17 & EMCDDA & 32 & 7 & $21,9 \%$ \\
\hline 18 & EMSA & 36 & 9 & $25,0 \%$ \\
\hline 19 & ENISA & 30 & 7 & $23,3 \%$ \\
\hline 20 & ERA & 36 & 10 & $27,8 \%$ \\
\hline 21 & ETF & 34 & 7 & $20,6 \%$ \\
\hline 22 & EUIPO (OHIM) & 31 & 5 & $16,1 \%$ \\
\hline 23 & EU-LISA & 30 & 7 & $23,3 \%$ \\
\hline 24 & EUROFOUND & 90 & 12 & $13,3 \%$ \\
\hline 25 & EUROPOL & 29 & 4 & $10,3 \%$ \\
\hline 26 & FRA & 31 & 7 & $22,6 \%$ \\
\hline 27 & FRONTEX & 30 & 3 & $10,0 \%$ \\
\hline
\end{tabular}


Annex 3. Descriptive statistics of the dependent and independent variables

\begin{tabular}{|l|c|c|c|c|c|}
\hline \multicolumn{1}{|c|}{ Variable } & Obs & Mean & Std. Dev. & Min & Max \\
\hline Decision-making & 107 & 0,804 & 0,399 & 0 & 1 \\
\hline Coordination & 104 & 0,827 & 0,380 & 0 & 1 \\
\hline Necessary resources & 100 & 0,420 & 0,496 & 0 & 1 \\
\hline $\begin{array}{l}\text { Causes accepted } \\
\text { Relevant players }\end{array}$ & 104 & 0,846 & 0,363 & 0 & 1 \\
\hline PhD degree & 112 & 0,277 & 0,449 & 0 & 1 \\
\hline Regulatory agencies & 125 & 0,456 & 0,500 & 0 & 1 \\
\hline $\begin{array}{l}\text { Risk profile } \\
\text { agencies }\end{array}$ & 125 & 0,432 & 0,497 & 0 & 1 \\
\hline
\end{tabular}

Note: agencies with a response rate $>15 \%$

\begin{tabular}{|l|c|c|c|c|c|}
\hline Variable & Obs & Mean & Std. Dev. & Min & Max \\
\hline Decision-making & 90 & 0,778 & 0,418 & 0 & 1 \\
\hline Coordination & 88 & 0,807 & 0,397 & 0 & 1 \\
\hline Necessary resources & 84 & 0,417 & 0,496 & 0 & 1 \\
\hline $\begin{array}{l}\text { Causes accepted } \\
\text { Relevant players }\end{array}$ & 88 & 0,830 & 0,378 & 0 & 1 \\
\hline PhD degree & 93 & 0,269 & 0,446 & 0 & 1 \\
\hline Regulatory agencies & 104 & 0,433 & 0,498 & 0 & 1 \\
\hline $\begin{array}{l}\text { Risk profile } \\
\text { agencies }\end{array}$ & 104 & 0,394 & 0,491 & 0 & 1 \\
\hline
\end{tabular}

Note: agencies with a response rate $>20 \%$ 
Annex 4. Logistic regression for perceived effectiveness in decision-making and coordination, as well as availability of resources to face transboundary crises

\begin{tabular}{lccc}
\hline & $\begin{array}{c}\text { Effectiveness } \\
\text { Decision making }\end{array}$ & $\begin{array}{c}\text { Effectiveness } \\
\text { Coordination }\end{array}$ & Necessary resources \\
\hline Regulatory agencies & $-0.79 .$. & -0.05. & $2.40^{* * *}$ \\
Risk profile agencies & $(0.59)$ & $(0.56)$ & $(0.49)$ \\
& $-0.85 .$. & $-1.29 * *$ & $0.12 .$. \\
PhD degree & $(0.57)$ & $(0.55)$ & $(0.47)$ \\
& $0.60 .$. & 0.17. & $0.50 .$. \\
Causes accepted & $(0.63)$ & $(0.64)$ & $(0.46)$ \\
Relevant players & $1.94 * * *$ & $1.45^{* * *}$ & $0.81 .$. \\
& $(0.36)$ & $(0.54)$ & $(0.53)$ \\
Constant & 0.42 & 1.02 & $-2.44 * * *$ \\
& $(0.76)$ & $(0.82)$ & $(0.61)$ \\
Observations & 80 & 80 & 76 \\
Clusters & 13 & 13 & 13 \\
Pseudo R & 0.17 & 0.12 & 0.23 \\
\hline
\end{tabular}

Note: Numbers in parentheses represent standard errors. Significant at $* \mathrm{p} \leq .10 ; * * \mathrm{p} \leq$ $.05 ; * * * \mathrm{p} \leq .01$

Note: agencies with a response rate $>20 \%$ 